\title{
Hz. Mevlâna Düşüncesinde Barış Kavramının Sûfî Psikolojisi Açısından Tahlili $^{1}$
}

\author{
İbrahim IŞITAN \\ Doç. Dr., Selçuk Üniversitesi İslami İỉlimler Fakültesi \\ Assoc. Prof. Dr, Selçuj University, Islamic Sciences Faculty \\ Orcid ID: 0000-0003-2427-2476 \\ ibrahimisitan@hotmail.com
}

Öz

Sûfi gelenek, mânevî yaşamın merkezi olarak kalbi görür ve nefs ve ruhun kalbi ele geçirmek, kendi arzu ve isteklerini kalbe yerleştirmek için mücadele ettikleri gerçeğini kabul eder. Söz konusu bu mücadeleyi gerçekleştirmenin amacı nefsânî ve ruhânî arzu ve isteklerin insan benini ele geçirme arzusudur. Bu durumun yol açabileceği içsel kaosa karşı sûfî yaşam tarzının önerdiği model nefse karşı mücâhede etmek ve ruhî müşâhedeyi kazanmaktır. Böylece içsel barış sağlanır, bireysel ve sosyal planda sağlıklı davranış kalıpları elde edilir. Bu çerçeveden bakıldığında yaşadığı dönemden itibaren günümüze kadar Doğu ve Batı dünyasında etkisini sürdürmüş olan Mevlâna Celaleddin Rumî'nin barış değer yargısının oluşmasındaki katkısı yadsınamaz bir durum arz etmektedir. Dönemindeki siyasi ve sosyal olayların karmaşıklığı karşısında Hz. Mevlâna barıştan yana tavır almış, sosyal anlamda barışın gerçekleşebilmesi için içsel barış ortamının sağlanması gerektiğine vurgu yapmıştır. Biz de bu tebliğimizde Hz. Mevlâna düşüncesinde bireysel ve sosyal barışın sağlanmasının ilkelerini kısaca ele aldık.

Anahtar Kelimeler: Barış, Kalp, Mevlâna Celaleddin Rumî, Nefs, Ruh.

\section{Psychological Analysis of The Concept of Peace in Terms of Sufi Psychology In Mevlana Thought}

\begin{abstract}
The Sufi tradition sees the heart as the center of spiritual life and accepts the fact that it seeks to capture the heart of the soul and the soul and struggle to place their desires in the heart. In other words, the intention of realizing this struggle is the desire to capture human beings of intentional or spiritual desires and wishes. The model proposed by the Sufi lifestyle against internal chaos that this condition may cause is to struggle against the human soul and win spiritual obedience. Thus, inner peace is ensured, and healthy behavioral patterns are obtained on the individual and social plan. From this perspective, the contribution of the Mevlana Celaleddin-i Rumî, which has been influential in the Eastern and Western world since the day he lived, to the peaceful justice of the day and day is undeniable. In the face of the complexity of the political and social events of his time, Mevlana has taken the side of the peace side and emphasized that an inner peace environment should provided in order for peace to be realized in social sense. In this paper, we will consider the principles of providing individual and social peace in the mind of Mevlana in psychological terms.
\end{abstract}

Keywords: Peace, Heart, Mevlana Celaleddin-i Rumî, Human Soul, Spirit.

\footnotetext{
${ }^{1}$ Bu makale, 8-9 Aralık 2017 tarihinde Selçuk Üniversitesi Mevlâna Araştırmaları Enstitüsü tarafından Konya'da düzenlenen "4.Uluslararası Mevlâna Sempozyumu'"nda sunulan tebliğimizin makale formatında kaleme alınmış şeklidir.
} 


\section{Giriş}

Birey ve toplumların barış içerisinde birlikte yaşama meselesi insanlık tarihi kadar eskidir. İlk insan Hz. Âdem'in çocuklarının farklı tavır içerisinde olmaları, birinin diğerinin kanını dökmesine yol açmış ${ }^{2}$ ve birlikte yaşamanın zorluğu konusu insanlık tarihinin en önemli problemlerinden biri olmaya başlamıştır. İnsanoğlunun dünya hayatına gönderilmesinden önce yaratılmış olan tabiat kendi içerisinde barışık doğal bir yaşam sürmekteyken, insanın yeryüzünde halife olarak yaşamaya başlaması dolayısıyla dünyevî imkânları kullanma hakkını elde etmiş ve aynı zamanda barışın gerçekleşmesine engel teşkil eden insanların birbirlerine karşı üstünlük sağlama/tekebbür savaşı da böylece başlamıştır. ${ }^{3}$

$\mathrm{Bu}$ noktada şu önemli soruyu sormak gerekmektedir. Dünyada yaşanan kargaşanın arka planında insan mı yoksa dünyanın kendisi mi var? Dünyanın olduğunu söylemek çok doğru gözükmemektedir çünkü insansız dünya yukarıda ifade ettiğimiz gibi - barış içerisinde kendi tabii seyrinde varlığını devam ettirebilmektedir. Bu durumda dünyanın ve sahip olduğu özelliklerin bizatihi problem teşkil etmesi söz konusu değildir. Öyleyse dünyada yaşanan kaosun kaynağı insandır demek daha doğrudur çünkü varlığı ve eşyayı kullanma yetkisine sahip olan insandır ve onun dünyaya bakış tarzı ve kullanma biçimi problemin kaynağını oluşturmaktadır. Bu nedenle insan tabiatını tanımak dünyada yaşanılan kaosun ve problemlerin kaynaklarını görme açısından önem arz etmektedir. ${ }^{4}$

\footnotetext{
${ }^{2}$ Kabil'in Habil'i öldürme olayı için bk. Kuran, Maide, 5/27-40.

${ }^{3}$ Tekebbür, büyüklük duygusu olan kibrin eyleme/davranışa dönüşmüş hali olarak değerlendirilmiştir. Tekebbürün en ileri derecesi Yaratıcıya karşı büyüklenerek kulluk yapmamayı tercih etme davranışıdır. Tevâzuun karşıtı olan kibir kendini büyük, başkalarını küçük görme olarak tarif edilmiştir (Mustafa Çağrıcı, 'Kibir', Diyanet Vakfı İslâm Ansiklopedisi (DİA), (İstanbul: Türkiye Diyanet Vakfı, 2002), c. XXV, s. 562). Kibrin mânevî bir hastalık olduğunu ifade eden sûfîler tedavi yöntemi olarak da tevâzu tutumuna sahip olmayı önerirler çünkü tevâzuda alçakgönüllü olma ve kendini başkalarından daha aşağıda görme duygusu vardır (Bk. İbrahim Işıtan, Sûfi Psikolojisi, Sülemi'ye Göre Sûfi Benlik Dönüşümü, Ankara, Divan, 2014, s. 240-243).

4 İnsanın yeryüzünde sorumlu varlık olduğunu, fakat hem Şeytana hem de Yaratıcıya uyma gibi zıt iki tutuma da meyilli olduğunu Kuran ortaya koymaktadır (Bakara, 2/30-37). Bununla birlikte insandan istenen ve beklenen yüzünü iyiliğe çevirmektir ve yanlış yaptığında da kötülükten geriye adım atma yani tevbe davranışını göstermektir. Bu nedenle sûfîler tevbeyi mânevî yolculuğun ilk makamı olarak kabul ederler (bk. Ebû Nasr Serrâc Tûsî, El-Lüma', İslâm Tasavvufu, ter. Hasan Kâmil Yılmaz, İstanbul, Altınoluk, 1996, s. 43).
}

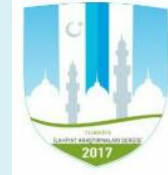

Türkiye İlahiyat Araştırmaları Dergisi 
Tarih boyunca dinî ve felsefî düşünce ve sistemler insan tabiatı hakkında çeşitli ve farklı fikirler ortaya koymuşlardır. İlahî dinlerin son halkası olan İslam dini etrafında gelişen dinî düşünceler de insan tabiatını çeşitli boyutlardan ele almışlardır. Bu düşünce modellerinden biri de İslam mâneviyatı olarak kabul edilen sûfî gelenektir. Sûfîler, insan tabiatında görünüşte zit olarak nitelendirebileceğimiz iki ana unsur bulunduğunu fakat bunların eğitilip uzlaşarak insan-1 kâmil diye adlandırılan mânevî anlamda kendini gerçekleştirmiş insanın ortaya çıkacağını ifade ederler. ${ }^{5} \mathrm{Bu}$ iki ana unsur nefs ve ruh olarak kabul edilmektedir; nefs dünyevî arzu ve istekleri temsil eder ve insan tutum ve davranışlarının gelişim yeri olan kalbi bu yönde etki altına almaya çalışır. Ontolojik anlamda kötülüğün/şerrin dış temsilcisi olarak addedilen şeytanın insan benliğinde ilişki kurduğu kuvvetin da nefs olduğunu dikkate alırsak, insanda kötülüğün kaynağı olarak nefsi görmek gerekmektedir. Buna karşın, ruh ise ilâhî, rahmânî ve melekî arzu ve istekleri temsil eder ve kalbi bu yönde etki altına almaya çalışır. ${ }^{6}$ Mânevî gelişim yeri olan kalp bu iki gücün etkisi ve çatışması altında yaşar. Buna göre insan beni kendi içerisinde bir gelişim ve dönüşüm sürecine girme durumuyla karşı karşıya kalır.

İnsan beninin bir çatışma içerisinde olduğu gerçeğini kabul eden sûfî gelenek, bu çatışmanın barışla sonuçlanması için kötülüğün kaynağı nefse ve şeytana karşı mücâhede etmeyi önermiş ${ }^{7}$ ve bunun sonucunda ruhî müşâhedenin yani hakikati olduğu gibi görebilme gücünün gerçekleşeceğini savunmuştur. ${ }^{8} \mathrm{Bu}$ noktada, sûfî geleneğe göre, bireysel ve sosyal barışın sağlanabilmesi için genelde bütün varlığın ve özelde ise insan tabiatının hakikatini tanıma bilgisini veren ruhî keşiflerin sağlanması ve böylece eşyanın hakikatini olduğu gibi müşâhede etmenin gerekliliğini söylemek gerekmektedir. Çünkü insanın nefsânî arzularının kaynağı olan bedensel arzu ve istekler oluşturdukları mânevî perdeler nedeniyle varlığın ve eşyanın gerçek boyutunu görmeye engel teşkil ederler. ${ }^{9} \mathrm{Bu}$ durumda yapılması gereken iş, her türlü engele/perdeye

${ }^{5}$ Tasavvufta 'insan-1 kâmil' anlayışı konusunda bilgi almak için örnek olarak bk. Cafer Karataş, 'Muhyiddin İbn Arabî' ye Göre İnsan-1 Kâmil' Uludă̆ Üniversitesi İlahiyat Fakültesi, c. 7, s. 7, (1998): s. $453-465$.

${ }^{6}$ Bk. Abdulkerim Kuşeyrî, Kuşeyrî Risalesi, ter. Süleyman Uludağ, İstanbul, Dergâh, 1991, s. 222223.

7 Ali b. Osman Cüllâbî Hucvîrî, Keşfu'l-mahcûb, Hakikat Bilgisi, trc. Süleyman Uludăg, İstanbul, Dergâh, 1996, s. 314-321.

${ }^{8}$ Bk. Süleyman Uludağ, 'Müşâhede', Diyanet Vakfı İslâm Ansiklopedisi (DİA), (İstanbul: Türkiye Diyanet Vakfı, 2006), c. XXXII, s. 153.

9 Sûfî literatürde hicab/perde salikle Hak arasında bulunan ve O'nu tanımaya engel olan her şeydir. İnsan beninde bulunan her gücün perdeleri farklıdır: Nefis, kalp, akıl, ruh ve hafînin her birinin kendine has bir perdesi vardır. Nefsin perdesi arzular, kalbin perdesi Hak'tan başkasını düşünme, aklın perdesi mâkuller, ruhun perdesi temaşâ, hafînin perdesi de ilâhî azamet ve kibriyâdır (bk. Süleyman Uludă̆, 'Hicab', Diyanet Vakfı İslâm Ansiklopedisi (DİA), (İstanbul: Türkiye Diyanet Vakfı, 1998), c. XVII, s. 430-431).

Türkiye İlahiyat Araştırmaları Dergisi Turkey Journal of Theological Studies [Tiad: 2602-3067]
Cilt / Vol : 2, Say1/Issue: 1 , 2018 
karşı tavır almak/mücâhede etmek ${ }^{10}$ ve bütün mevcûdâtın aslını ve kaynağını teşkil eden ilâhî varlığın zâtî ve sıfâtî özelliklerini keşfederek, insan tutum ve davranışlarına model olmalarını sağlamaktır. ${ }^{11}$

Söz konusu edilen ruhî keşiflerin sağlanarak bireysel ve sosyal barışın kazanılması için sûfîler bazı metotlar geliştirmiş ve bunları uygulamaya koymuşlardır. Bunlardan en önemlisi insandaki nefsânî arzu ve istekleri uyandıran dünya ve dünyadakilere karşı ilgisiz kalmayı/zühdü öğrenmektir. ${ }^{12}$ Çünkü bir şeye karşı ilgi ve alaka devam ettikçe ona karşı olan sevgi ve bağlılık daha da artar. Bu nedenle fâni görülen ve sadece vazifeyi yerine getirebilmek için bir müddet geçici ve emanet olarak verilen dünyevî varlıklara karşı gereğinden fazla ilgi göstermemeyi öğrenmek, insan için en temel vazife olarak kabul edilmiştir. ${ }^{13}$ Buna göre barışın sağlanabilmesi ile dünyaya ilgi duymamak arasında doğrudan ilişki vardır.

Sûfî geleneğin öngördüğ̈̈ zühd yaşamının gerçekleşmesi dünyevî ve uhrevî beklentilerden uzak olma şartına bağlıdır. Çünkü dünya ve âhiret nimetleri insan zihnini çeker ve kalp bunlarla ilgilenmeye başlarsa, kişi bu nimetlere karşı ihtiraslı bir duruma düşer. Her türlü nimete karşı mesafe koymak ve yalnız Yaratıcının rızasını ve memnuniyetini aramak içsel huzuru ve sosyal barışı sağlamak için gerekli görülmüştür. ${ }^{14}$

Sûfî geleneğin ortaya koyduğu zühd anlayışının temel amaçlarından biri de, İslam dininin hedeflemiş olduğu ihsan/Rabbini görüyormuş gibi kulluk yapma tavrını hayata geçirme hedefidir. ${ }^{15}$ Çünkü dünyaya karşı ilgisi ve hırsı olmayan kişi elindeki maddî ve mânevî imkânları ihsan duygusu çerçevesinde insanlığın

\footnotetext{
${ }^{10}$ Mücâhede kavramı hakkında geniş bilgi almak için bk. Abdulkerim Kuşeyrî, Kuşeyrî Risalesi, s. 235-239; Kelâbâzî, Ta'arruf, Doğuş Devrinde Tasavouf, ter. Süleyman Uludağ, İstanbul, Dergâh, 1992, s. 202-205.

${ }^{11}$ Bk. Kelâbâzî, Ta'arruf, Doğuş Devrinde Tasavvuf, s. 180-181.

${ }^{12}$ Bk. İbrahim Işıtan, Sûfi Psikolojisi, s. 104-108.

${ }^{13}$ Bk. İbrahim Işıtan, Sûfî Psikolojisi, s. 131-132.

${ }^{14}$ Sûfî literatürde rızâ, mânevî yolculuğun en son duraklarından/makam ve menzillerinden biri olarak kabul edilmektedir. Genel anlamda rızâ, kalbin Allâh'ın kadîm irâdesine nazar ederek ilâhî kaderin hüküm ve kararları karşısında sükûnetle sevinç duyması ve ıstırap çekmemesidir. Çünkü kişi Yaratıcının kendisi için en iyisini seçtiğini bilir ve bu nedenle öfke duygusunu göstermeyi bırakır (Tûsî, El-Lüma', İslâm Tasavvufu, s. 51-52).

15 Tasavvuf ilminin ihsan olarak da kabul edilmesi, sûfî hayatın Allâh'ın varlığını hissederek yaşamayı hedeflediğini göstermektedir. Buna göre Yaratıcıyı görerek yaşama duygu ve düşüncesi hayatı iyilik yapma üzerine kurma anlamına da gelmektedir. İhsan konusunda daha çok bilgi almak için bk. Mustafa Çağrıcı, 'İhsan', Diyanet Vakfı İslâm Ansiklopedisi (DİA), (İstanbul: Türkiye Diyanet Vakfı, 2000), c. XXI, s. 544-546.
}

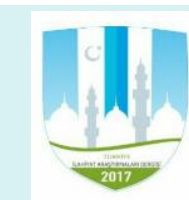

Türkiye İlahiyat Araştırmaları Dergisi 
faydasına kullanma/hizmet etme tutumunu sergileme imkânı elde eder. ${ }^{16} \mathrm{Bu}$ durum yaşamın iyilik ve yardımlaşma üzerine kurulması anlamına gelmektedir. Bu çerçeveden bakıldığında, sûfî birey ve grupların kendilerini hizmete adamaları ve kendi ihtiyaç ve çıkarlarından daha çok başkalarının ihtiyaç ve çıkarlarını öne çıkarmaları/îsâr ${ }^{17}$ barış ortamının sağlanmasında etkili bir yöntem olarak kabul edilebilir. Sûfî söylem ve uygulamalar dikkatle incelendiğinde kendilerine karşı sert fakat başkalarına karşı yumuşak ve şefkatle davranma biçimi öne çıkar. ${ }^{18} \mathrm{Bu}$ durum bireyi kendi ihtiyaçlarını sınırlama ve elindeki imkânları başkaları için kullanma tutumunu benimsemeye iter. ${ }^{19}$ Her noktada azimetle yani zor olanı yapmakla ${ }^{20}$ kendini sorumlu hisseden sûfî birey, bu tavrı sayesinde, başkalarının hata ve kusurlarıyla değil, kendinde bulunan hata ve kusurlarla ilgilenir ${ }^{21}$ ve bu tutum diğer bireylerle barış içerisinde yaşamayı kolaylaştırır.

Sûfî yaşam tarzının başkalarının hatalarını görmeme tutumunu öne çıkarması, kişilerarası ilişkilerde affetme prensibinin uygulanmasını sağlamaktadır. ${ }^{22}$ Sûfî uygulamada diğer insanların bize karşı yaptıkları olumsuz durumlarda ilâhî

16 Sûfîler maddî ve mânevî bütün imkânları insanlığa hizmet olarak kullanmayı/cûd ve sahavet tutumunu benimserler ve hatta zekât verecek derecede mal bile biriktirmedikleri için de zekât verme durumunda kalmazlar (Bk. Hucvîrî, Keşfu'l-mahcûb, Hakikat Bilgisi, s. 454-455). Sûfî yolda bulunan müridin malını ve canını Yaratıcının emrine uygun şekilde harcaması beklenir. Buna göre sûfî, mânevî gelişim yolunda malını ve canını feda eden bireydir (Bk. Hucvîrî, Keşfu'lmahcûb, Hakikat Bilgisi, s. 459).

17 "İhtiyaçları bile olsa, onları (kardeşlerini) kendilerine tercih ederler" (Kuran, Haşr, 59/2) âyetini model alan sûfîler, diğer bireylerin ihtiyaçlarını öne çıarma tutumunu tercih etmişlerdir (bk. Bk. Hucvîrî, Keşfu'l-mahcûb, Hakikat Bilgisi, s. 301-302; İbrahim Işıtan, Sûfî Psikolojisi, s. 149-153).

18 Şefkat konusunda bk. İbrahim Işıtan, Sûfî Psikolojisi, s. 168-169.

${ }^{19}$ Nefsin arzu ve isteklerini sınırlama ve azla yetinme tutumu konusunda bk. İbrahim Işıtan, Sûfî Psikolojisi, s. 133-136.

${ }^{20}$ Sûfîler, bireyin kendi çıkarlarına kullanma ihtimaline karşı, ruhsatlarla yani dinen verilmiş izinlerle hareket etmeyi tercih etmemişler, azimetle yani dinen daha meşakkatli kabul edilen kuralları uygulamaya koymayı salık vermişlerdir. Bu tercih insanlar arası ilişkilerde ve toplumda barışın yaşama geçirilmesine yardımcı bir unsurdur. Çünkü zor olanı tercih etmek başkalarının ve toplumun menfaatini öne çıkarmakla doğru orantılıdır. Ayrıca bir bireyin veya grubun zor olanı tercih etmesi diğer birey ve grupları da zor olanı tercih etmeye yönlendirir. Bu durum toplumda ahlakî anlamda en üst düzeyde davranma durumunu ortaya çıkarır ve böylece barış ortamının sağlanmasına doğrudan katkıda bulunur (bk. İbrahim Işıtan. 'Kuşadalı İbrahim Halvetî’ye Göre Mânevî Şahsiyet Gelişimi', İnsan ve Toplum Bilimleri Araştırmaları Dergisi, c. V, s. 6, (2015): s. 1705-1706; Süleyman Uludağ, 'Ruhsat', Diyanet Vakfi İslâm Ansiklopedisi (DİA), (İstanbul: Türkiye Diyanet Vakfı, 2008), c. XXXV, s. 210).

${ }^{21}$ Bk. İbrahim Işıtan, Sûfî Psikolojisi, s. 136-140.

${ }^{22}$ Dinî yaşamın affedicilik üzerine etkisi söz konusudur. Bu konuda örnek olarak bk. Ali Ayten, 'Affedicilik ve Din: Affetme Eğilimi ve Dindarlıkla İlişkisi Üzerine Ampirik Bir Araştırma', Marmara Üniversitesi İlahiyat Fakültesi Dergisi, c. XXXVII, (2009): s. 111-128.

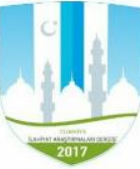


hikmetleri arama düşüncesi öne çıkar ${ }^{23}$ ve böylece yapılan yanlışların bizden de kaynaklanabileceğini hesaba katma tutumu davranış planında kendini gösterir. Bu ruh hali içerisinde olan sûfî bireyin diğer insanların kendisine karşı yaptığ yanlışları affetmesi ve hatta görmemesi mümkün hale gelir. Buna karşın sûfî bireyin Yaratıcıya ve topluma karşı yapılan hataları aynı oranda affetmediği görülmektedir çünkü söz konusu olan Allah ve kamu hakkıdır. Buna göre, nefsine karşı durabilme eğilimi sûfî bireyi ben merkezli yaşamaktan çıkarmakta ve Yaratıcı ve toplum için davranabilme kıvamına kavuşturmaktadır. ${ }^{24} \mathrm{Bu}$ hareket tarzının bireysel ve sosyal barışı kazanma merkezli çalışmadan kaynaklandığını söylemek mümkündür.

Toplumsal anlamda barış içerisinde birlikte yaşamın üst düzeyde sağlanmasının en temel özelliklerinden biri de adaleti sağlamaktır. Adaletin sağlanmadığı yani herkese hakkının verilmediği toplumlarda barışın sağlanması mümkün değildir. Sûfî yaşamın kendini gerçekleştirme adına her şeye hakkını vererek hayata geçirme arzusu bu anlamda önem arz etmektedir. ${ }^{25}$ Bilginin, düşüncenin, dikey ve yatay bütün ilişkilerin her türlü sahtelikten ve ikilikten uzak olmasını öngören sûfî yol, her türlü bağın ve ilişkinin hakîkat sevgisi üzerine kurulmasını gerekli görür. Hakîkat ilmini arama ve bu çerçevede hikmetli davranmayı öne çıkarma seyrü sülûkun hem gereği hem de hedefi olarak kabul edilmiştir. Bu zorunluluk ve amaç - yukarıda ifade edildiği gibi - bireysel çıkar ve beklentileri geriye bırakmayı ve diğer insanların ihtiyaç ve menfaatlerini öne çıkarmayı gerektirir.

Sûfî geleneğin bu ve benzeri yaşam prensipleri sosyal hayatta güvenin sağlanması ve dolayısıyla barışın temin edilmesi bakımından önem arz eder; bireysel ve sosyal anlamda güvenin sağlanması barış ortamının meydana gelmesine doğrudan etki eder. Bu konuda psikoloji biliminde yapılan araştırmalar bireyin doğumundan itibaren çevresine güven duygusuyla

${ }^{23}$ İlâhî fiillerde hikmetin bulunması konusunda bilgi almak için bk. Emrullah Yüksel, 'İlâhî Fiillerde Hikmet', Atatürk Üniversitesi Ilâhiyat Fakültesi, c. VIII, (1988): s. 43-76. Tasavvuf literatüründe hikmet kavramı üzerine bilgi almak için bk. Mustafa Kara, 'Hikmet', Diyanet Vakfı İslâm Ansiklopedisi (DIA), (İstanbul: Türkiye Diyanet Vakfı, 1998), c. XVII, s. 518-519.

${ }^{24}$ Sûfî birey dinî inancı gereği Allâh'a bağlanma tutumunu benimser ve bunun için dünyevî olana tavır alır (bk. İbrahim Işıtan, Sûfî Psikolojisi, s. 129-132.

${ }_{25}$ Adâlet, ferdi ve içtimaî yapıda dirlik ve düzenliği, hakkaniyet ve eşitlik ilkelerine uygun yaşamayı sağlayan bir erdem olarak (Mustafa Çağrıcı, 'Adâlet', Diyanet Vakfi İslâm Ansiklopedisi (DİA), (İstanbul: Türkiye Diyanet Vakfı, 1998), c. I, s. 341), sûfî yolculuğun gerçekleştirmek istediği ahlâkî hedeflerden biridir. Kurân-1 Kerim'in adâleti engelleyen temel unsurlardan birinin nefsin hevâsi/arzusu olduğunu belirtmesi (bk. Abdurrahman Kasapoğlu, 'Kur'an'da Adalet Psikolojisi - Adaleti Engelleyen Psiko-Sosyal Faktörler', Hikmet Yurdu, c. V, s. 10, (2012): s. 66-71), sûfîlerin nefsin hevâsına karşı durma tutumuna sahip olmalarının önemini göstermektedir (bk. Hucvîrî, Keşfu'l-mahcûb, Hakikat Bilgisi, s. 309-313).

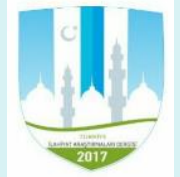

Türkiye İlahiyat Araştırmaları Dergisi 
bağlanmasının önemini ortaya koymuş ve bu durumun insan ruh sağllğ açısından değerini belirtmiştir. Bireysel ve sosyal anlamda güven duygusundan mahrum olan insanların strese girmeleri ve depresyona düşmeleri daha çok rastlanan bir durum olarak ortaya konmuştur. ${ }^{26}$

Kısaca tekrar ifade edersek, tasavvuf geleneği açısından bakıldığında, sûfî yaşamın - bireysel olması yanında - bir grup içerisinde hayata geçirilmesi ve bunun da birtakım mânevî ve ahlâkî kurallara dayandırılması barış içinde birlikte yaşama kültürüne katkısını artırmaktadır. Sûfî birey mânevî yolculuğunu içsel anlamda derinleştirip ilk önce Yaratıcına ulaşmayı hedefler ve bu aşamadan sonraki yaşam dönemini insanî ve gerçekçi bulur. Bu nedenle sûfî birey Mevlâ'sına kavuşmadan önce yaşadığı hayatı çocukluk dönemi olarak telakki eder, vuslata erdikten sonraki yaşam dönemini de yetişkinlik devri olarak görür.

\section{Hz. Mevlâna'da Barışı Sağlamanın Temel Bazı İlkeleri}

Giriş kısmında barışın sağlanması konusunda sûfî psikolojisi açısından ifade ettiğimiz fikirleri şimdi de Hz. Mevlâna' nın düşüncesi zaviyesinden ele alalım. Konuyu daraltma açısından dört başlık altında sunmayı uygun gördük: Dünyayı âhireti kazanma aracı olarak görme, alt benliğin/nefs-i emmârenin arzu ve isteklerine sınır koyma, mânevî hürriyet/fakr makâmını yaşama, vahdet makâmında bulunma. Metot olarak, Hz. Mevlâna'nın söz konusu bu dört konudaki fikirlerini ele alacak ve bireysel ve sosyal barışın sağlanmasına doğrudan veya dolaylı olarak etkisini ve katkısını ele alacağız.

\section{a) Dünyayı Âhireti Kazanma Aracı Olarak Görme}

Giriş bölümünde kısaca ifade ettiğimiz gibi, sûfî açıdan bakıldığında, bireysel ve sosyal barışın sağlanması kişinin dünya ve dünyevî olana bakış tarzıyla ilgilidir. Barışın sağlanması dünya şartlarında olacağına göre, insanın dünyaya hangi gözle baktığı önem arz etmektedir. Yukarıda ifade ettiğimiz gibi sûfî bakış dünyanın ve dünyevî olanın geçiciliği üzerine durur, kalıcı ve uhrevî olana ilgi duyulması gerektiği fikrini öne çıkarır. Bu konuda Hz. Mevlâna şöyle der: "Dünyayı isteyen, olmayacak kötü şey istedi. Öteki dünyayı isteyen iyi bir durum istedi.", "Bu dünya zindandır ve bizse zindandakiler. Zindanda çukur kaz ve kendini kurtar! ${ }^{27 "}$

Hz. Mevlâna bu ifadeleriyle dünyanın zindan olduğunu, insanların da bu zindanda yaşayan mahpuslar olduğunu ve kişinin kendini bu zindandan kurtarması gerektiğini belirtir. Dünyanın hapishane olarak kabul edilmesi,

${ }^{26}$ Güven ortamının toplumsal barış için önemi bilinen bir gerçektir çünkü güven duygusunun zayıfladığı toplumlarda sosyal ilişkiler istenilen düzeyde gelişmez ve barış ortamının oluşması engellenmiş olur (bk. Ömer Müftüoğlu, 'Güven Ortamının Bir Toplum İçin Önemi ve Bunu Engelleyen Faktörler', Din Bilimleri Akademik Araştırma Dergisi, c. V, s. 2, (2005): s. 143-159).

${ }^{27}$ Mevlâna Celâleddîn Rûmî, Mesnevî, çev. Adnan Karaismailoğlu, İstanbul, Akçağ, 2004, s. 67.

Türkiye İlahiyat Araştırmaları Dergisi Turkey Journal of Theological Studies [Tiad: 2602-3067]
Cilt / Vol : 2, Say1/Issue: 1, 2018 
uzun süre yaşanılacak bir yer olmadığı anlamına gelmektedir. Nasıl ki mahpus olan birey bir an önce hapishaneden çıkma arzusu taşırsa, mümin kişi de asıl vatanının âhiret yurdu olduğunu bilir ve bu dünyadan kurtulma savaşı verir. Dünyadan kurtulma savaşı bir an önce bedensel ölümü tercih etmek değildir çünkü hapishane olan dünyada gerçekleştirilmesi gereken bir hedef vardır: Kendini ve Rabbini tanımak. ${ }^{28}$ Buna göre, sûfî bakış tarzına göre dünya ve dünyevî olandan kurtuluşun yolu seyrü sülûku/mânevî yolculuğu gerçekleştirerek beden hapsinden kurtulmak ve ruhun hürriyet alanına girmektir. Çünkü söz konusu bu yolculuk sayesinde kalp dünyevî arzu ve isteklerin etkisinden kurtulur ve kendini ruhî arzu ve isteklerin tesirine birakır. $^{29}$

$\mathrm{Bu}$ çerçeveden bakıldığında, dünya ve dünyalık denen, kişiyi Yaratıcıdan alıkoyan şeydir, yoksa dünyanın kendisi değildir. Çünkü dünyanın kendisi âhireti kazanmak için araçtır ve mânevî gelişim için gerekli bir mekândır. Bu noktayı Hz. Mevlâna şöyle dile getirir: “Dünya nedir? Allah'tan gâfil olmaktır; kumaş, para, tartı ve kadın değil. Din için yüklendiğin mal hakkında Resûl, 'Helal mal ne güzel' dedi..30". Bu ifadelere göre dünya Yaratıcının tutum ve davranış olarak etkisinin olmadığ 1 her türlü tavır ve hareket olarak değerlendirilebilir. Buna göre dinî bir vazife bile icra edilmiş olsa, eğer Allah rızası dışında bir kaygıyla yapılıyorsa bu, dünya olarak kabul edilir. ${ }^{31}$ Tam tersine dünyalık gibi gözüken

\footnotetext{
${ }^{28}$ Sûfî yolculuğun hedefi, nefsi tanımak ve dolayısıyla Rabbi tanımak olarak belirlenmiştir: Mârifetü'n-Nefs ve mârifetu-r-Rab. İnsan merkezli bir bilgi teorisini esas alan tasavvufî düşüncede, insanın kendini tanıması temel ilkedir. Sûfî, nefsi hakkında edindiği bilgiden hareket ederek Hakk'ın bilgisine ulaşır. İnsanın Hakk'a dair bilgisi nefsine dair bilgisi ölçüsünde olduğundan Hakk'ı daha iyi bilmesi için nefsini/kendini daha iyi tanıması gerekir. Tasavvufta Hakk'a dair bilgiye 'mârifet-i Hak' (mârifetullah), salikin kendine dair bilgisine de 'mârifet-i nefs' denir (Süleyman Uludağ, 'Ma'rifet-i nefs', Diyanet Vakfi İslâm Ansiklopedisi (DİA), (İstanbul: Türkiye Diyanet Vakfı, 2003), c. XXVIII, s. 56-57). Sûfîler bu anlayışı 'Nefsini bilen Rabbini bilir' sözüyle/hadisiyle ifade etmişlerdir. Bu sözün kaynağı hakkında bk. Yusuf Açıkel, 'Nefsini Bilen Rabbi'ni Bilir' Hadis mi, Kelam-1 Kibar Mr?', Süleyman Demirel Üniversitesi İlâhiyat Fakültesi, c. V, (1998): s. 173-200.

${ }^{29}$ Sûfî gelenekte seyrü sülük bireyin maddî boyutunun etkilerinden kurtulmak için bu âleme gelmeden önceki durumuna yeniden kavuşma çalışmasıdır (bk. İbrahim Işıtan, 'Sadreddin Konevî’ye Göre Sûfî Psikolojisi, Konevî Düşüncesinde Sûfi Kişilik Yapısının Temel Dayanakları', Tarih Kültür ve Sanat Araştırmaları Dergisi, c. I, (2012): s. 2, s. 171).

${ }^{30}$ Mevlâna Celâleddîn Rûmî, Mesnevî, s. 67.

31 Sûfîler yaptıkları fiil ve davranışlarında 'huzûru' ararlar. Bu anlamda huzur iki türlüdür: Birincisi huzur-i kalb ki kalbin, saflık sayesinde, gözden gâib olan sevgilisinin yanında hazır olması anlamına gelir. İkincisi ise huzur-i Hak ki sâlikin Hakk'ı kalbinde hazır bulması manasına gelir (Süleyman Uludağ, Tasavouf Terimleri Sözlü̆̆̈̈̈, İstanbul, Marifet, 1996, s. 251). Bu nedenle sûfîler kalbin Hakk'ın huzurunda olmamasını ve Hakk'ın da kalpte hazır olmama durumunu gaflet olarak değerlendirirler (Bk. İbrahim Işıtan, Sûfî Psikolojisi, s. 210-216; Süleyman Uludağ,
}

Türkiye İlahiyat Araştırmaları Dergisi 
bir işi Yaratıcının hoşnutluğunu kazanmak adına yaptığımızda, bu davranışımız dünyalık olmaktan çıkar ve âhiret yatırımı olarak kabul edilir. Bu anlayışa göre dünya ve âhiret ayrımı söz konusu değildir çünkü dünya âhiret hayatını hazırlayan bir yaşam dilimidir. Hz. Mevlâna bu konuda şöyle der: "Cihan sence büyük ve sonsuz ise de, kudret önünde onu, var olmayan bir zerre bil. Bu cihan, bizzat sizin ruhlarınızn hapishanesidir. Acele edin! Ovanız olan yöne gidin. Bu cihan sınırl, o ise bizatihi sınırsız. Suret ve şekil, bu mananın önünde engeldir.32" Sûfîmizin bu sözleri içinde yaşadığımız dünyanın sınırları olması nedeniyle ruhumuz için zindan olduğunu ve buradan sınırsız ve sonsuz âlem olan âhirete doğru kaçmak gerektiğini ifade etmektedir. Kısaca ifade edersek, bireysel ve sosyal barışın sağlanması için, dünyada yaşamak fakat onun bir parçası olmamak gerekmektedir. ${ }^{33}$

$\mathrm{Bu}$ açıklamalara göre dünya barışının sağlanması, âhiret hayatı adına davranışlar göstermekle doğru orantılıdır. Dünyaya aldırmadan ve dünyevî olana takılmadan davranma gücüne erişen birey yaşamını öteki dünya hedefine yönelik düzenler ve dünyevî kavgalardan uzak yaşar. Sonuç itibariyle, dünyadan uzak ve âhirete yakın olma hali insan fiillerinin gelişim mekânı olan kalpte huzur, sükûn ve barışın oluşmasına yol açar ve bireyin dengeli bir benlik örgüsü kurmasına zemin hazırlar.

Dünyayı âhireti kazanma aracı olarak görmek için kişinin nefs-i emmârenin arzu ve isteklerine sınır koyabilme cesaretini göstermesi gerekmektedir. Aksi takdirde bireyin yüzünü ölümden sonrası yaşama yönlendirmesi mümkün olmaz ve dolayısıyla da dünya hayatında bireysel ve sosyal anlamda huzur ve barışı kazanamaz. Şimdi alt benliğin ben merkezli arzu ve isteklerine sınır koyma konusunda Hz. Mevlâna'nın görüşlerine geçebiliriz.

\section{b) Alt Benliğin/Nefs-i Emmârenin Arzu ve İsteklerine Sınır Koyma}

Dünyayı âhireti kazanma aracı olarak değerlendirebilme, yukarıda belirttiğimiz gibi, ancak alt benliğin arzu ve isteklerine karşı durmak ve sınır koymakla mümkündür. Çünkü mânevî gelişmeyi gerçekleştirememiş kişi dünyevî ilgi ve ilişkilere bağımlı yaşar. Bu nedenle, kişiyi bu durumdan kurtarmak için arzu ve isteklerine karşı mücâhede etmek mânevî gelişim için vazgeçilmez bir zorunluluktur. Aksi takdirde kişinin yapıp ettiklerinden kendisi ve başkaları için olumlu sonuçlar çıkmaz ve hatta kendisi ve başkaları için zararlı davranışlar meydana gelir. ${ }^{34} \mathrm{~Hz}$. Mevlâna bu konuyu şöyle

'Gaflet', Diyanet Vakfı İslâm Ansiklopedisi (DİA), (İstanbul: Türkiye Diyanet Vakfı, 1996), c. XIII, s. 283-284).

32 Mevlâna Celâleddîn Rûmî, Mesnevî, s. 53.

${ }^{33}$ Bk. Robert Frager, Kalp, Nefs, Ruh, çev. İbrahim Kapaklıkaya, İstanbul, Gelenek, 2005, s. 37-38.

34 Sûfîlerin sözünü ettikleri nefse karşı mûcahede etmenin karşısında en büyük engellerden biri de tembellik ve kurallara uymama tutumlarıdır (bk. İbrahim Işıtan, Sûfì Psikolojisi, s. 219-223, 225-

Türkiye İlahiyat Araştırmaları Dergisi Turkey Journal of Theological Studies [Tiad: 2602-3067]
Cilt / Vol : 2, Say1/Issue: 1 , 2018 
vurgular: "Kalem rüzgârdan ve defter sudan olursa, ne yazarsan çabucak yok olur. Mânasız söz sudaki şekildir; onda vefa ararsan, ellerini ısırarak pişman olursun. Rüzgâr insandaki arzu ve istektir. Arzuyu bırakırsan, Hakk'ın haberidir. Yaratıcının haberleri hoştur, çünkü onlar baştan ayağa ebedîdir. ${ }^{35 " ~ S u ̂ f i ̂ m i z i n ~ b u ~ s o ̈ z l e r i ~ n e f s i n ~ a r z u ~ v e ~}$ isteklerine göre davranmanın suya yazı yazmak gibi kalıcı bir etki bırakmayacağını ve yaşamın boşa harcanması demek olduğunu ifade eder. Çünkü bilinçli bir şekilde organize olmadan, Yaratıcının isteklerine cevap vermeden ve yalnız nefsin arzu ve isteklerini tatmin etmek için icra edilen fiiller/davranışlar dünya hayatında kalır ve âhiret yaşamına ulaşmaz. Buna mukabil nefsin hevâ ve heveslerini terk ederek hareket kabiliyeti geliştirme Allah'tan haber yani ilham alma fırsatını doğurur ve böylece kişi ebedî/kalıcı fiiller icra etme imkânı elde eder. ${ }^{36}$

Hz. Mevlâna "Padişahların heybeti, arzudandır/hevâdandır. Peygamberlerin büyüklük nedeni ise Yüce Allah'tandır. Padişahların adları paralardan silinir. Ahmed'in adı ise sonsuza dek işlenir. ${ }^{37 "}$ der. Bu ifadeler Tanrı buyruğuna kulak vermeden kendi arzu ve isteklerine göre hareket eden yöneticilerin işlerinin sonuç vermeyeceğini, buna karşın peygamberlerin işlerinin ilahî emirlere göre hareket etmelerinden kaynaklandığını belirtmektedir. Çünkü Kuran ifadesine göre peygamberler kendi hevâ ve heveslerinden konuşmaz, onların konuşması vahiyden başka bir şey değildir. ${ }^{38}$

Sûfî gelenek içerideki düşmanımız olan nefsimizle olan mücâhedeyi büyük cihat olarak değerlendirir çünkü nefsin hile ve tuzakları her zaman açık ve net değildir. Hz. Mevlâna bu konuda şunları söyler: "Ey padişahlar! Dıştaki düşmanımızı öldürdük. İçimizde ondan daha kötü bir düşman kaldı. Bunu öldürmek, aklın ve zekânın işi değildir. İçteki aslan, tavşanın oyuncă̆ı değildir. Bu nefis cehennemdi, cehennem ise ejderhadır. O denizlerle eksilip azalmaz...Bu nefsimiz cehennemin parçası olduğu için, parçalar da daima bütünün tabiatını taşır. ${ }^{39 "}$

232). Bu nedenle sûfîler nefsin zincirlerinden kurtulmak için sürekli çalışmayı ve hizmeti esas almışlardır. Bu çerçeveden bakıldığında, başkalarına yük olmamak ve hatta başkalarına hizmet etmek sûfî yolun en temel gereklerinden biri olarak kabul edilmiştir (Robert Frager, Kalp, Nefs, Ruh, s. 42-43).

${ }^{35}$ Mevlâna Celâleddîn Rûmî, Mesnevî, s. 71-72.

${ }^{36}$ Sûfî yolun ortaya koyduğu fenâ ve bekâ anlayışı geçici olanın etkisini kalpten atmak ve kalıcı olanın tesirini kalbe yerleştirmek içindir. Geçici hazları arzu eden nefsin istekleri kırılmadan, kalıcı olan rûhun hazlarının benliğe yerleşmeyeceğini belirten sûfîler, hedef olarak ilâhî sıfatların tecellîlerini kalbe yerleştirme savaşı verirler (bk. Hucvîrî, Keşfu'l-mahcûb, Hakikat Bilgisi, s. 365371; Mustafa Kara, 'Fenâ', Diyanet Vakfi İslâm Ansiklopedisi (DİA), (İstanbul: Türkiye Diyanet Vakfı, 1995), c. XII, s. 333-335).

${ }^{37}$ Mevlâna Celâleddîn Rûmî, Mesnevî, s. 71-72.

${ }^{38}$ Kuran, Necm, 53/3.

${ }^{39}$ Mevlâna Celâleddîn Rûmî, Mesnevî, s. 81. 
Sûfîmizin bu açıklamaları insanın içinde bulunan nefsin düşmanların en büyüğü olduğunu ve onunla savaşmak için de Hakk'ın desteğini almaktan başka çare olmadığını ifade eder. Çünkü insanın kendi başına bu savaştan galip çıkması mümkün değildir. ${ }^{40} \mathrm{Bu}$ durumda Hakk'ın nefs hakkında bildirdiği bilgilere kulak vermek ve nefisle mücâhede edebilmek için koyduğu kuralları uygulamaya koymak gerekmektedir. Hz. Mevlâna bunu şu sözleriyle dile getirir: "Nefsi öldürecek ancak Hakk'ın ayarıdır/iradesidir. Onun yayın Hakk'tan başka kim çekebilir? Yaya ancak doğru ok konur. Bu yayın ters ve eğri okları vardır. Ok gibi doğru ol, yaydan kurtul. Çünkü yaydan şüphesiz doğru oklar sıçrar. Dış savaştan dönünce, iç savaşa yöneldim. -Biz-"Küçük cihattan döndük"üz. Peygamber'le büyük cihattayız. ${ }^{41 " ~ S u ̂ f i ̂ m i z i n ~ b u ~ s o ̈ z l e r i ~ n e f s e ~ k a r s ̧ ı ~ s a v a s ̧ ı ~ a n c a k ~ H a k k ' 1 n ~ o ̈ n d e r l i g ̆ i n d e ~}$ ve Hz. Peygamber (sav)'in rehberliğinde başarabileceğimizi ortaya koymaktadır. Çünkü Hz. Peygamber (sav) nefsin tabiatını ve onunla nasıl mücadele edilebileceğini Hakk'tan öğrenmiş ve bize bunu sünnetiyle göstermiştir. ${ }^{42}$

$\mathrm{Bu}$ açıklamalar ışığında bireysel ve sosyal barışın sağlanması için kendi çıkarlarından daha çok evrensel değerler adına davranma kabiliyeti gösteren insan ve insan gruplarına ihtiyaç vardır. Bütün insanlığın çıkarları düşünülmeden ve sadece bir bölgenin veya bir grubun menfaatleri adına hareket ederek dünya barışını sağlamak mümkün değildir. İnsan tabiatına uygun değer yargıları ve davranış kalıpları ile hareket etmek bu açıdan önem arz eder.

Hz. Mevlâna'nın ifadelerinden hareketle şunu söylemek mümkündür: Alt benliğin çıkara ve menfaate dayalı beklentilerinden uzaklaşma imkânı bulamamış bireyin, içsel barışını ve dolayısıyla sosyal barışını keşfetmesi mümkün değildir çünkü kalp hangi duygu ve düşüncelerle hareket ederse ona göre şekil alır. Bu gerçekten hareketle, alt benliğin kendi çıkar ve menfaatlerinden kurtulması mânevî hürriyetin sağlanmasıyla doğru orantılıdır. Şimdi Hz. Mevlâna'nın bu konudaki görüşlerine geçebiliriz.

\section{c) Mânevî Hürriyet/Fakr Makâmını Yaşama}

\footnotetext{
40 Sûfî yaşam tarzının bir kılavuz eşliğinde gerçekleşmesinin nedeni kendi başına Allâh'ın iradesine uyma gücüne sahip olamamasıdır. İradesini kuvvetlendirmiş bir mürşidin örnek davranışlarını taklit ederek, sâlik nefsine karşı savaşta başarı elde eder. Mürşide uymanın anlamı ve değeri konusunda bk. Himmet Konur, 'Mesnevî'de Mürîd-Mürşid İlişkisi', Tasavvuf, c. XIV, (2005): s. 149-151.

${ }^{41}$ Mevlâna Celâleddîn Rûmî, Mesnevî, s. 81.

42 Sûfî yolda rehber Hz. Peygamber (sav)'dir çünkü o Hakk'ın rehberliğinde hakikati bütünüyle uygulamaya koymuştur. Bu nedenle sûfîler Hz. Peygamber (sav)'i örnek almayı prensip olarak kabul etmişlerdir. Sûfîlerin Hz. Peygamber'e uymaları konusunda bilgi almak için bk. Tûsî, ElLüma', İslâm Tasavoufu, s. 93-105.
}

Türkiye İlahiyat Araştırmaları Dergisi Turkey Journal of Theological Studies

[Tiad: 2602-3067]
Cilt / Vol : 2, Say1/Issue: 1, 2018 
Dünya hayatını âhiret yurduna hazırlanma aracı olarak telakki etme ve bu nedenle, alt benliğin arzu ve isteklerine sınır koyma, sonuç itibariyle sûfî bireyde mânevî hürriyetin/fakrın oluşmasına yol açmaktadır. Hiçbir şeye bağlanmamayı ve sadece Yaratıcıya kul olmayı hedefleyen bu özgürlük anlayışı bireye dünyaya karşı ilgi duymama ve dünyayı yalnızca âhiret için bir hazırlanma yeri olarak değerlendirme imkânı verir. Bu nedenle sûfîler fakrı bir makam olarak kabul ettikleri gibi hedef olarak da görmektedirler.

Hz. Mevlâna bu konuda şunları söyler: 'Mal ve saltanatı gönlünden kovduğu için Süleyman kendisini sadece miskin/yoksul diye adlandırdı. Havayla dolu, ă̆zı kapalı testi, büyük suyun üstünde gider. Dervişlik/yoksulluk havası içte olunca, insan dünya suyu üstünde kalır. Bu dünyanın bütün mülkü onun olsa da, onun gönül gözünde mülk bir şey değildir. Öyleyse gönül ağzını bağla ve mühürle. Onu Min ledün/Hak katından ululuk havasıyla doldur. ${ }^{43 "}$ "Sûfîmizin bu sözleri fakr makamının oluşması için kalbin dünya malı ve makamlarıyla ilgisinin kalmamasının gerektiğini vurgular. Dünya ve dünyalığın elde olması mânevî gelişime engel değil, tam tersine yardımcı bir unsurdur çünkü insan dünya şartlarında mânevî yolculuğunu gerçekleştirme durumundadır. Buna göre aslolan dünyevî imkânları elde bulundurmamak değil, bu imkânlar konusunda gönlün ilgisini kırmaktır. ${ }^{44} \mathrm{Bu}$ duruma eren bireyin davranışları kalıcı etki bırakır ve insanlığın barış ve mutluluğuna doğrudan katkı sağlar.

Sûfîlerin fakr/mânevî hürriyet anlayışı çerçevesinde bakıldığında, dünyanın fakr tutumuna uygun davranan yöneticiler tarafından yönetilmesi dünya barışının sağlanmasında önemli bir nokta olarak gözükmektedir. Çünkü dünyada gözü olan yöneticilerin idare tarzlarında dünyevî ilişki ve menfaatler öne çıkar ve bu da adaletin sağlanmasına ve dolayısıyla güven ortamının oluşmasına engel teşkil eder. Bu nedenle yöneticinin mânevî hürriyet ve mânevî sultanlık anlamına gelen fakr tutumuna sahip olması önem arz eder. Hz. Mevlâna bu durumu Hz. Ömer (ra) örneği üzerinden şöyle anlatır: "Rum Kayserinden Medine'deki Ömer'e derin çölden bir elçi geldi. 'Ey yiğitler! Halifenin sarayı nerede? Atımı ve eşyamı oraya çekeyim' dedi. Millet ona dedi: 'Onun sarayı yoktur, Ömer'in sarayı aydınlık bir candır. Her ne kadar beyden dolayı şöhreti olsa da dervişler gibi bir kulübesi vardır. Ey kardeş! Onun sarayını nasıl görürsün? Çünkü senin gönül gözünde kıl bitmiş. Gönül gözünü, kıldan ve hastalıktan temizle. O zaman onun sarayın görmeyi ümit et. Arzulardan canı temiz olan, pak huzuru ve eyvanı

${ }^{43}$ Mevlâna Celâleddîn Rûmî, Mesnevî, s. 67-68.

44 Sûfîler bu durumu fakr makâmıyla ifade ederler. Fakr, her şeyin dünyevî boyutunun kaybolması ve uhrevî olanın kalbi kuşatması anlamına gelir. Fakr kavramı hakkında geniş bilgi almak için bk. Tûsî, El-Lüma', İslâm Tasavvufu, s. 46-48; Kelâbâzî, Ta'arruf, Doğuş Devrinde Tasavouf, s. $144-146$. 
hemen görür. Muhammed bu ateş ve dumandan pak olunca, nereye yöneldiyse Allâh'ın cemâli vardı. Sen kötü istekli vesvesenin arkadaşı iken 'Allah'ın yüzü̈/kıblesi oradadır' ${ }^{\prime}$ ' nasıl bilirsin. ${ }^{45 " ~ S u ̂ f i ̂ m i z i n ~ b u ~ i f a d e l e r i ~ y o ̈ n e t i c i ~ m a k a m ı n d a ~ b u l u n a n ~ k i s ̧ i n i n ~}$ dünyadan yeteri kadariyla yetinme duygusuna sahip olup himmetini ve gayretini âhirete yönlendirmesinin önemini göstermektedir. Çünkü mânevî hürriyetini sağlamış bir yönetici dünyevî ilgi ve ilişkileri konusunda güven duygusu oluşturacaktır. İnsanlararası ilişkilerde düşmanlığın oluşması ve dolayısıyla barış ortamının ortadan kalkmasının temel nedenlerinden biri de dünyevî menfaatlerin paylaşım sorunudur. Dünyaya karşı hırslı olan kişiler hedeflerine ulaşmak için çeşitli hile ve manipülasyonlara girebilmekte ve toplumların yönetimini bu çerçevede etkileyebilmektedirler. $\mathrm{Bu}$ nedenle yönetici grubunun mânevî ilke ve prensipleri yaşamlarında ve yönetim tarzlarında uygulamaya koymaları, dünyevî konularda eleştirilere maruz kalmalarına engel olur ve adalet, güven ve barış ortamının sağlanması daha kolay gerçekleşir.

İnsanların tutum ve davranışlarında ağırlıklı olarak ya heybet durumu ya da muhabbet durumu yansır. ${ }^{46}$ Fakat özellikle idareci olan bireylerde bu iki halin dengeli bir şekilde bulunması adaletin sağlanması bakımından önemlidir. Sûfî yaşam tarzının ortaya koyduğu fakr tutumu içerisinde olmanın idareci konumundaki bireye hem heybet hem de muhabbet hallerini kazandıracağını söylemek mümkündür. Çünkü idarecinin tutum ve davranışlarında adalet, güven ve barış gibi değerleri yaşama geçirmesi diğer özelliklere bağlı olduğu gibi hem heybet hem de muhabbeti bir arada yansıtmasına da bağlıdır. Hz. Mevlâna bu durumu Hz. Ömer örneği üzerinden şöyle anlatır: "Rum Kayserin'den gelen elçi oraya gelip durdu. Ömer'i görerek titremeye başladı. Elçiye o uyuyandan bir korku geldi. Canına hoş bir hâl çöktü. Sevgi ve korku birbirine zıttır. Bu iki zıddı gönlünden bir arada gördü. Kendi kendine dedi: Ben padişahları gördüm. Sultanların yanında büyük ve seçkin kişiyim. Padişahlardan korkum ve endişem yoktu. Bu adamın heybeti aklımı kapıp aldl. Aslan ve kaplan ormanına gittim, yüzüm onlardan dolayı rengini değiştirmedi. Nice savaşta, harpte bulundum. Savaş olduğunda aslan gibiydim. Nice ă̆ır yaralar aldım, nice ă̆ır yaralar açtım. Başkalarından daha cesurdum. Bu adam silahsız, yerde uyumuş; bense bütün vücudumla titriyorum, nedir bu? Bu Hakk'ın heybetidir, halktan değildir. Bu abalı adamın heybeti değildir. ${ }^{47 "}$ Sûfîmizin bu sözleri fakr tutumuna sahip idarecinin korku ve sevgi hislerini bir

${ }^{45}$ Mevlâna Celâleddîn Rûmî, Mesnevî, s. 83-84.

${ }^{46} \mathrm{Bu}$ iki halin aynı insanda bulunması nadir olan bir haldir. Hz. Peygamber (sav)'in şahsında, birçok özellik gibi, zıt olarak değerlendirilebilecek heybet ve muhabbet durumları da dengeli bir şekilde mevcuttu. İdeal insan Hz. Peygamber (sav)'i örnek alması gereken Müslüman idarecilerinin de bu iki durumu birlikte yaşamaları adalet, güven ve barışı telkin etmek bakımından önem arz etmektedir.

${ }^{47}$ Mevlâna Celâleddîn Rûmî, Mesnevî, s. 81-82.

Türkiye İlahiyat Araştırmaları Dergisi Turkey Journal of Theological Studies [Tiad: 2602-3067]
Cilt / Vol : 2, Say1/Issue: 1, 2018 
arada yansıttığını ve böylece insan-ı kâmil olarak Allâh'ın Celal ve Cemal sıfatlarının birlikte tecellîsine sahne olduğunu göstermektedir. ${ }^{48}$ İnsanın yeryüzünde Allâh'ın halifesi olması dikkate alındığında, insanda potansiyel olarak bulunan zıt kutupların dengeli bir şekilde davranışa yansıması gerekmektedir. Özellikle de toplumu idare eden bireylerin söz konusu bu dengeye sahip olması adaletin sağlanması, güven ve barış ortamının oluşması için önem arz etmektedir.

Söz konusu ettiğimiz bütün bu tutum ve davranışlar vahdet/birlik halinin yaşanmasıyla doğru orantılıdır. Çünkü vahdet hali bireye tavır ve hareketlerini bir bütün halinde ele almasını sağlamaktadır. Şimdi sûfîmizin vahdet konusundaki görüşlerine geçebiliriz.

d) Vahdet Makâmında Bulunma

Bütün ilâhî dinler gibi İslam dini de Allâh'ın birliği (vahdet) ve dolayısıyla varlığın kaynağının birliği üzerine kuruludur. Yaratıcının bir olduğunu kabul etmek aynı zamanda yaratılanların da Bir'den meydana geldiği anlamına gelmektedir. ${ }^{49} \mathrm{Bu}$ inanç biçimi sûfî düşünce tarzında tecellî kavramıyla ifade edilmektedir. ${ }^{50}$ Sûfî anlayışa göre bütün varlık Allâh'ın isim ve sıfatlarının tecellîleri olarak kabul edilir. Buna göre varlıkta esas olan birliktir/vahdettir ve çokluk/kesret ise izafidir. Bu çerçeveden bakıldığında sûfî yaşamın öngördüğü mânevî yolculuğun/seyrü sülükün amacı çokluk dünyasından kurtulmak ve vahdet deryasında fenâ bulmaktır. Hz. Mevlâna özümüzdeki vahdete vurgu yaparak şöyle der: "O tarafta hep yayılmıştık ve bir cevherdik; hep başsız ve ayaksızdık. Güneş gibi bir cevherdik. Dertsiz ve su gibi saftık. O kusursuz ışık, suret hâline gelince kale burçlarmin gölgeleri gibi adet oldu. ${ }^{51 " ~} \mathrm{Bu}$ ifadeler cevherimizin/özümüzün aynı olduğunu fakat suretlerimizin farklı olduğunu ve bu nedenle de çokluğun oluştuğunu ifade etmektedir. Sûfîmiz bu durumdan kurtulmak gerektiğini şu sözleriyle ortaya koyar: "Manalarda bölüm ve sayı yoktur. Manalarda parçalamak ve ayırmak yoktur. Dostun dostlarla birleşmesi hoştur. Mananın ayağına yapış, suret isyankârdır. Altındaki hazine gibi vahdeti/birliği görmek için isyankâr sureti, eziyetle erit. ${ }^{22}$ " Bu sözler suret ve şekillerin farklılıklarından dolayı mânadaki birlik ve bütünlüğün görülmediğini ve bu nedenle de ayrılıkların meydana geldiğini göstermektedir. Mâna yani insan olma

\footnotetext{
48 Sûfî literatürde tecellî kavramı Yaratıcının sıfatlarının kulda tutum ve davranışlar olarak belirmesi ve böylelikle beşerî sıfatların ortadan kalkması anlamına da gelir. Bu konuda daha çok bilgi almak için bk. Kelâbâzî, Ta'arruf, Doğuş Devrinde Tasavvuf, s. 180-182.

${ }^{49}$ Kelâbâzî, Ta'arruf, Doğuş Devrinde Tasavouf, s. 61-62; Kuşeyrî, Kuşeyrî Risalesi, s. 473-479.

${ }^{50}$ Bk. Semih Ceyhan, 'Tecellî', Diyanet Vakfi İslâm Ansiklopedisi (DİA), (İstanbul: Türkiye Diyanet Vakfı, 2011), c. XL, s. 241-243.

${ }^{51}$ Mevlâna Celâleddîn Rûmî, Mesnevî, s. 58.

52 Mevlâna Celâleddîn Rûmî, Mesnevî, s. 58.
} 
bakımından ortak olduğumuz diğer insanları dışlamak ve elimizdeki maddî ve mânevî değerleri onlarla paylaşmamak işte bu parçalanmış kişilik ve benlik nedeniyledir. Nefs ruhuyla bütünleşmediğinde insanda ikilik meydana gelmekte ve bu durum benmerkezci ve diğer insanları dışlayıcı bir tutum içerisinde yaşamı perçinlemektedir. Bu nedenle Hz. Mevlâna şöyle der: "Surete/görünüşe bakarsan, gözün ikidir. Sen gözden doğan ışı̆̆a bak. Kişi, ışığına baktığında, her iki gözün ışı̆̆ııı ayıramaz. Bir yerde on kandil bir araya getirilse her biri görünüşte birbirinden başkadır. Işıklarına yüzünü çevirince, şüphesiz her birinin

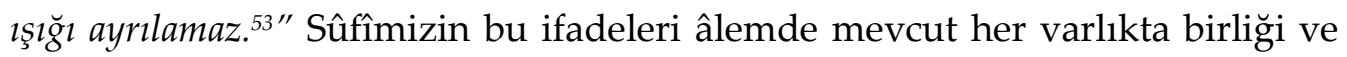
vahdeti görmek gerektiğinin altını çizmektedir. Bu durumda varlıktaki birlik Yaratıcının bir olmasından kaynaklanmaktadır. Bu nedenle her şeyden önce Yaratıcının birliğini ve dolayısıyla varlığın birliğini kavramak gerekmektedir. Bu noktada Hz. Mevlâna şöyle der: "Biz kim oluyoruz? Ey, sen bize cansin; can. Nasıl olur da, biz seninle bir arada oluruz? Biz yoklarız ve bizim varliklarımız sensin; fani görünen mutlak varliksın. ${ }^{4{ }^{\prime \prime}}$

Hz. Mevlâna'dan hareketle tevhid ve vahdet konusunda ifade ettiğimiz bu düşünceler insanlığı ve varlığı bir bütün olarak ele almanın ve buna göre toplumları inşa etmenin önemini ortaya koymaktadır. ${ }^{55}$ Toplumsal bütünlüğün ve barışın sağlanmasının insanlığı bir bütün olarak görmekten geçtiğini ifade etmektedir. Yaşama ve olaylara bir bütün halinde bakmanın adalet, barış ve güven gibi değer yargılarının toplumda daha kolay yerleşmesine neden olacağını söylemek mümkündür. Fakat bu birliği ve bütünlüğü göremeyen kişiler farklılıkları gerçek kabul eder ve çatışma ortamının oluşmasına yol açarlar. Hz. Mevlâna “Onun, İsâ'nın tek renkliliğinden nasibi yoktu, İsâ küpünün mizacından huyu yoktu. Yüz renkli elbise, bu berrak küple saba rüzgârı gibi sade ve tek renk olurdu ${ }^{56 "}$ sözüyle farklılıkların yolun hakikatinden değil, gidiş yollarının çeşitliliğinden kaynaklandığını ortaya koymaktadır. Bu durumda zahirî anlamda dillerin farklı olması ayrı insanlar olduğumuzu göstermez. Aynı dili konuşup anlaşamayan insanlar olduğu gibi, ayrı dilleri konuştukları halde gönül diliyle anlaşan insanlar da vardır. Bunu sûfîmiz "Aynı dili kullanmak, akrabalık ve bağhlıktır. Insan, yakın olmayanlarla bir arada tutsak gibidir. Nice aynı dili konuşan Hindu ve Türk vardır, nice yabancılar gibi iki Türk vardır. Öyleyse

\footnotetext{
${ }^{53}$ Mevlâna Celâleddîn Rûmî, Mesnevî, s. 58.

${ }^{54}$ Mevlâna Celâleddîn Rûmî, Mesnevî, s. 55.

55 Yaratıcının gönderdiği dinî değer yargıları aslında bütün insanların huzur ve mutluluğunu hedef edinmektedir. Fakat dinin insan eliyle bozulması ve kendi çıkarları için manipüle edilmesi bu hedefin gerçekleşmesine engel teşkil etmektedir. İlâhî dinlerin son halkasını teşkil eden İslam dinî asliyetini korumakta fakat müntesiplerinin dini bütün boyutlarıyla uygulamaya koyamamaları nedeniyle İslam toplumlarında evrensel değerleri uygulayacak medeniyet algısı oluşamamaktadır. İslam dininin ortaya koyduğu evrensel değerlerin yeniden anlaşılması için sûfî geleneğin ortaya koyduğu tarihsel tecrübeden istifade edilmelidir.

${ }^{56}$ Mevlâna Celâleddîn Rûmî, Mesnevî, s. 52.
}

Türkiye İlahiyat Araştırmaları Dergisi Turkey Journal of Theological Studies [Tiad: 2602-3067]
Cilt / Vol : 2, Say1/Issue: 1, 2018 
yakınlık dili bizatihi başkadır. Gönüldaşlık, dildaşlıktan daha iyidir ${ }^{57 "}$ sözleriyle dile getirir. Bu açıklamalar ışığında dünya barışının sağlanması gönül dilini geliştirmeye bağlıdır demek mümkündür.

\section{Sonuç}

Bireysel ve toplumsal barışın sağlanması birçok unsurun ve değer yargısının birlikte yaşama geçirilmesiyle doğru orantılıdır. İlâhî dinlerin son halkası olan İslam dininin ortaya koyduğu değer yargılarının dünya barışını sağlayacak imkâna sahip olduğunu söylemek mümkündür. Bu çerçevede İslam mâneviyatı olarak kabul edilen sûfî geleneğin katkısı da önem arz etmektedir çünkü sûfîlerin ortaya koydukları yaşam tarzı insan fıtratında mevcut olan ahlâkî ve mânevî değer yargılarını hayata geçirme konusunda daha etkili motivasyonlara sahiptir. Çünkü sûfî birey bütün varlığını Yaratıcısına ait gördüğü için maddî ve mânevî bütün imkânlarını Hak ve Hakikat yolunda harcamaktan kaçınmaz. Yaratana hizmetin yaratılana hizmetten geçtiğini kabul eden sûfî birey kendi çıar ve huzurundan daha çok çevresindeki insanların ihtiyaçlarını ve mutluluğunu düşünür. Çıkar ve menfaatlerin çatıştığ durumlarda Yaratıcısını memnun etme adına diğer kişilerin lehine tercihte bulunur. Söz konusu bu tercihi yapabilmek için alt benliğin arzu ve isteklerini sınırlama çalışması yapan sûfî birey, bu sayede benmerkezci olmaktan kurtulur ve bütün varlıkla birlikte yaşama sanatını öğrenir. İnsan huzurunu bozan temel unsurların sınır tanımayan nefsânî arzu ve istekler olduğu gerçeğinden hareketle, bireysel huzuru bozacak tutum ve davranışları benliğinden atarak mânevî gelişim yeri olan kalbini mânevî arzu ve isteklerin kaynağı olan ruhunun emrine verir. Böylece bireysel barışı sağlayarak toplumsal barışa da katkıda bulunmuş olur.

Sûfî hayatın ortaya koyduğu yaşam tarzı insan üzerine inşa edildiği için ötekileştirme problemini çözücü ve birlikte barış içerisinde yaşamayı sağlayan prensiplere sahiptir. Ötekileştirme probleminin insanlar ve toplumlar arası ilişkilerde barışı bozucu bir özelliğe sahip olduğunu göz önüne alırsak, sûfî geleneğin ortaya koyduğu prensipleri barışı sağlama noktasında modern şartlara cevap verici nitelikte yeniden ele almak gerekmektedir. Makalemiz bu konuya katkı sağlamak amacıyla kaleme alınmıştır.

Bu çerçeveden bakıldığında, sûfî geleneğin en önemli temsilcilerinden biri olan Hz. Mevlâna'nın ortaya koyduğu anlayışın ve yaşam biçiminin, bireysel ve toplumsal barışın sağlanmasına ve dolayısıyla dünya barışının gerçekleştirilmesine katkısını ele almak önem arz etmektedir. Çünkü Hz. Mevlâna, kendi döneminde olduğu gibi daha sonraki devirlerde de etkisini

${ }^{57}$ Mevlâna Celâleddîn Rûmî. (2004), s. 75. 
sürdürmüş ve günümüzde de hala tesirini devam ettiren bir sûfî şahsiyettir. Bu tesirde birçok etki söz konusu olmakla birlikte tasavvuf tarihinde Hz. Rabia Adeviyye'nin temsil ettiği sevgi merkezli mânevî yolu benimsemiş olması daha çok etkili olmuştur. Hz. Mevlâna ilâhî aşk merkezli bir sûfî yolu öncelemiş ve nefs-i emmârenin hazlarını ilâhî aşk ateşiyle yakma yöntemini benimsemiştir.

$\mathrm{Bu}$ çerçeveden bakıldığında kardeşliğin sağlanması ve dünya barışının kurulması için mânevî şahsiyeti gelişmiş insan tiplerini incelemek, fikirlerini ve yaşam tarzlarını günümüz insanının hizmetine sunmak gerekmektedir. Hz. Mevlâna da bu şahsiyetlerin önde gelenlerinde biri olarak güncelliğini korumaktadır. Çünkü bu tip şahsiyetlerin söz ve uygulamaları ilâhî bilgi eşliğinde geliştiği için çağlar ötesi etki gücüne sahiptir.

\section{Kaynakça / Reference}

Açıkel, Yusuf, 'Nefsini Bilen Rabbi'ni Bilir' Hadis mi, Kelam-1 Kibar Mı?', Süleyman Demirel Üniversitesi İlâhiyat Fakültesi, c. V, (1998): s. 173-200.

Ayten, Ali, 'Affedicilik ve Din: Affetme Eğilimi ve Dindarlıkla İlişkisi Üzerine Ampirik Bir Araştırma', Marmara Üniversitesi İlahiyat Fakültesi Dergisi, c. XXXVII, (2009): s. 111-128.

Çağrıcı, Mustafa, 'Adâlet', Diyanet Vakfi İslâm Ansiklopedisi (DİA), (İstanbul: Türkiye Diyanet Vakfı, 1998), c. I, s. 341-343.

Çağrıcl, Mustafa, 'İhsan', Diyanet Vakfi İslâm Ansiklopedisi (DİA), (İstanbul: Türkiye Diyanet Vakfı, 2000), c. XXI, s. 544-546.

Çağrıcı, Mustafa, 'Kibir', Diyanet Vakfi İslâm Ansiklopedisi (DİA), (İstanbul: Türkiye Diyanet Vakfı, 2002), c. XXV, s. 562-563.

Frager, Robert, Kalp, Nefs, Ruh, çev. İbrahim Kapaklıkaya, İstanbul, Gelenek, 2005.

Hucvîrî, Ali b. Osman Cüllâbî, Keş̧fu'l-mahcûb, Hakikat Bilgisi, trc. Süleyman Uludağ, İstanbul, Dergâh, 1996.

Işıtan, İbrahim, 'Sadreddin Konevî'ye Göre Sûfî Psikolojisi, Konevî Düşüncesinde Sûfi Kişilik Yapısının Temel Dayanakları', Tarih Kültür ve Sanat Araştırmaları Dergisi, c. I, (2012): s. 2, s. 171.

Işıtan, İbrahim, Sûfî Psikolojisi, Sülemi'ye Göre Sûfí Benlik Dönüşümü, Ankara, Divan, 2014.

Işıtan, İbrahim, 'Kuşadalı İbrahim Halvetî’ye Göre Mânevî Şahsiyet Gelişimi', İnsan ve Toplum Bilimleri Araştırmaları Dergisi, c. 5, s. 6, (2015): s. 1705-1706.

Kara, Mustafa, 'Fenâ', Diyanet Vakfı İslâm Ansiklopedisi (DİA), (İstanbul: Türkiye Diyanet Vakfı, 1995), c. XII, s. 333-335. 
Kara, Mustafa, 'Hikmet', Diyanet Vakfi İslâm Ansiklopedisi (DİA), (İstanbul: Türkiye Diyanet Vakfı, 1998), c. XVII, s. 518-519.

Karataş, Cafer, 'Muhyiddin İbn Arabî'ye Göre İnsan-1 Kâmil' Uludă̆ Üniversitesi İlahiyat Fakültesi, c. VII, s. 7, (1998): s. 453-465.

Kasapoğlu, Abdurrahman, 'Kur'an'da Adalet Psikolojisi-Adaleti Engelleyen Psiko-Sosyal Faktörler', Hikmet Yurdu, c. V, s. 10, (2012): s. 61-106.

Kelâbâzî, Ta'arruf, Doğuş Devrinde Tasavouf, ter. Süleyman Uludağ, İstanbul, Dergâh, 1992.

Konur, Himmet, 'Mesnevî' de Mürîd-Mürşid İlişkisi', Tasavvuf, c. XIV, (2005): s. 149-157.

Kuşeyrî, Abdulkerim, Kuşeyrî Risalesi, çev. Süleyman Uludağ, İstanbul, Dergâh, 1991.

Müftüoğlu, Ömer, 'Güven Ortamının Bir Toplum İçin Önemi ve Bunu Engelleyen Faktörler', Din Bilimleri Akademik Araştırma Dergisi, c. V, s. 2, (2005): s. $143-159$.

Rûmî, Mevlâna Celâleddîn, Mesnevî, çev. Adnan Karaismailoğlu, İstanbul, Akçă̆, 2004.

Tûsî, Ebû Nasr Serrâc, El-Lüma', İslâm Tasavvufu, çev. Hasan Kâmil Yılmaz, İstanbul, Altınoluk, 1996.

Uludağ, Süleyman, Tasavvuf Terimleri Sözlü̆̆̈̈̈, İstanbul, Marifet, 1996.

Uludağ, Süleyman,Gaflet', Diyanet Vakfı İslâm Ansiklopedisi (DİA), (İstanbul: Türkiye Diyanet Vakfı, 1996), c. XIII, s. 283-284.

Uludağ, Süleyman, 'Hicab', Diyanet Vakfı İslâm Ansiklopedisi (DİA), (İstanbul: Türkiye Diyanet Vakfı, 1998), c. XVII, s. 430-431.

Uludağ, Süleyman, 'Müşâhede', Diyanet Vakfı İslâm Ansiklopedisi (DİA), (İstanbul: Türkiye Diyanet Vakfı, 2006), c. XXXII, s. 152-153.

Uludağ, Süleyman, Ruhsat', Diyanet Vakfı İslâm Ansiklopedisi (DİA), (İstanbul: Türkiye Diyanet Vakfı, 2008), c. XXXV, s. 210.

Yüksel, Emrullah, 'İlâhî Fiillerde Hikmet', Atatürk Üniversitesi İlâhiyat Fakültesi, c. VIII, (1988): s. 43-76. 